\title{
Managing agricultural biotechnology in Colombia
}

\author{
Ingrid Schuler* \\ Departmento de Biología \\ Facultad de Ciencias \\ Pontificia Universidad Javeriana \\ Bogotá, Colombia \\ Tel: 571 3208320. Ext. 4056-4091 \\ E-mail: ischuler@javeriana.edu.co \\ Luis Antonio Orozco \\ Vicerrectoría de Investigaciones y Doctorados \\ PhD Student - School of Management \\ Universidad de los Andes \\ Bogota, Colombia \\ Tel: 05713394949 \\ Fax: 05713324052 \\ E-mail: lorozco@uniandes.edu.co
}

Financial support: REDBIO/FAO.

Keywords: agricultural biotechnology, indicators, legislation, policies, public perception.

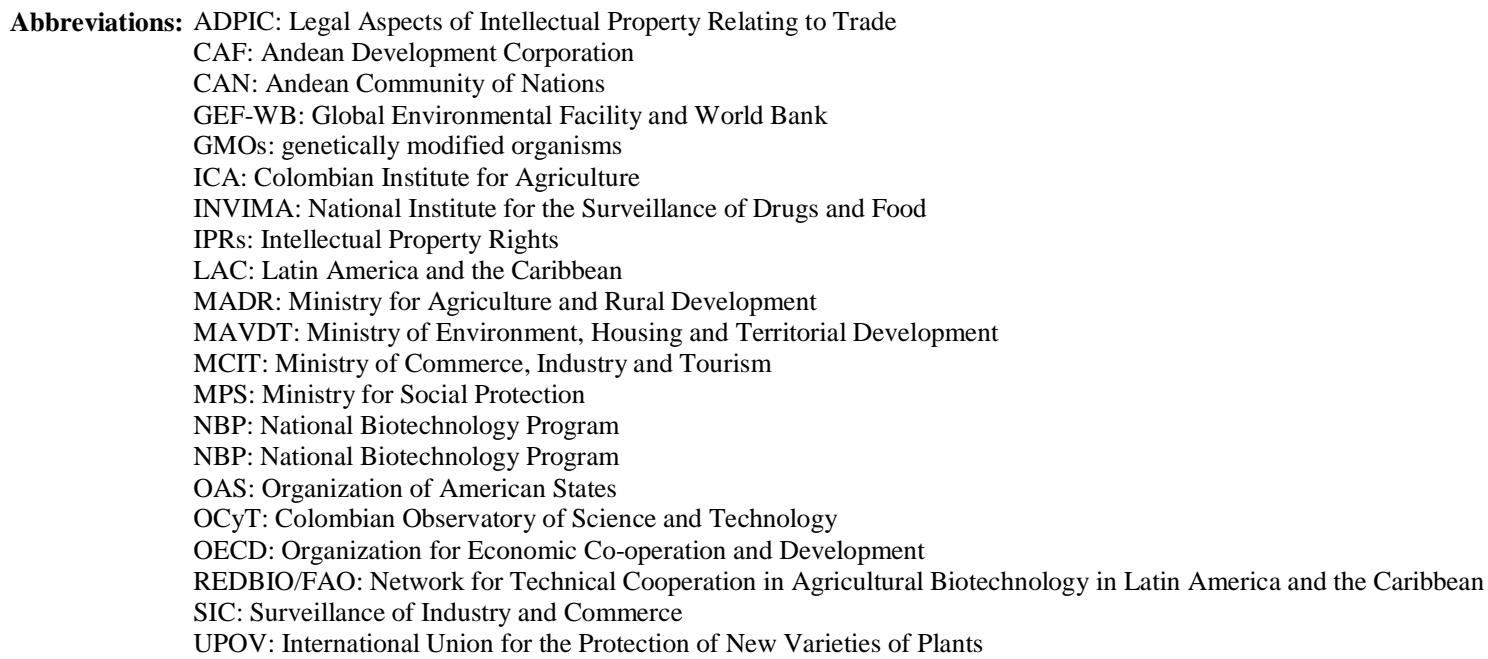

The international scenario for biotechnology shows a rapid tendency at industrialized countries in the increase of publications, patents, enterprises and novel solutions for the industry, the environment, health and agriculture. Nevertheless, Colombia has an important delay in relation to the international scientific development and the capacity to generate wealth and services for its productive systems. This delay has been one of the concerns of the country's policy during the last years, and more precisely since 2002, when for the first time biotechnology was included in a National Development Plan as one of the mechanisms for competitiveness and the use of biodiversity and genetic resources. This paper is the result of a survey conducted in 2005 aimed to provide an overview of agrobiotechnology in Colombia to be included in the compendium of case studies organized by the FAO's Regional Office for Latin America and the Caribbean (LAC) and the Network for Technical Cooperation in Agricultural Biotechnology in Latin America and the Caribbean (REDBIO/FAO).

The command of skills on classic biotechnologies in Colombia has allowed the strengthening of capacities, especially with micropropagation and cell and tissue culture. Nevertheless, the transition towards modern biotechnologies has been difficult, especially due to the

*Corresponding author 
scarcity of financial resources and the access to new technologies and specialized knowledge. Neither has the country a critical mass of economists, managers and lawyers to integrally support the processes of technological supervision, competitive intelligence, market access, national regulations and international treaties on intellectual property rights and biosafety.

The attention that necessities of small producers deserve, together with the improvement of the intellectual property rights, public perception and biosafety framework on genetically modified organisms (GMOs) for human and animal consumption, are some of the fields on which we should be working in the country through international networks, with an aim to reach the benefits that use of modern biotechnology brings along, as some researchers in this field have highlighted (Watal, 2000; Spielman et al. 2006). In this way, the current technological gap existing between countries of the South and the North could be bridged (Huete-Pérez et al. 2001; Byerlee and Fischer, 2002; Tollens et al. 2004).

\section{GENERAL BIOTECHNOLOGY INDICATORS}

Since 1999, organizations such as the Organization for Economic Co-operation and Development (OECD) and the Organization of American States (OAS) began to compile statistics to describe the situation of the countries that are developing biotechnologies. A general view shows that countries in Latin America and the Caribbean (LAC) have significant gaps with countries of the North, especially in patterns of patenting and licensing technologies, and that the transferal of biotechnologies is of vital importance, especially those biotechnologies developed for the agricultural sector (Testa, 2002; Heisey et al. 2005; Thumm, 2005; Chan, 2006).

In LAC countries, measurements mainly include the analysis of the capacity of groups and research centers, their working fields, the number of enterprises and the market perspectives, whereas the statistics of OECD measure mainly the private investment, the generation of investor's capital in terms of new companies, money and employment, and the obtainment of patents among other indicators, which are not so representative for us due to the differences in economies and development systems.

An indicator to analyze the state of biotechnology in the countries is a function of the investment made for its developments and products. The United States of America has a much higher investment tendency in relation to other countries. In 1997, the industry invested around US\$ 7.300 millions, being $3.7 \%$ of the total investment for research and development (NSF, 2004), and as for 2001 it reported that investment of industry in research and development of biotechnology reached US\$ 16.400 millions, representing $10 \%$ of the total investments in science and technology (U.S. Department of Commerce, 2003). European countries such as Germany, with more than US\$ 1.000 millions
(6.7\% of total), United Kingdom with US\$ 705 millions (7.8\% of total) and France with US\$ 560 millions having a $4.4 \%$ of the total of governmental investment in $\mathrm{R} \& \mathrm{D}$, follow the list with the largest assigned budget for biotechnology according to statistics of OECD (Van Beuzekom, 2001).

The situation in countries members of the OECD reveals a striking difference between USA and EU. According to data provided in 2001 by the consultant company Ernst and Young, USA investment in R\&D was $€ 11.400$ million (2.7\% of DGP) whilst EU investment was $€ 4.977$ million (1,8\% of DGP). There are 1,262 companies in USA totalling 162,000 employees and $6.7 \%$ of them are involved in research, in contrast to 1,570 companies in EU with 61,000 employees, $2.5 \%$ of them conducting research (Ernst and Young, 2001).

In the compendium of biotechnology statistics of OECD, differences can also be observed. The first one is the amount of investment in risk capitals in biotechnology, which goes up to US\$ 1.182 millions in the USA, and US\$ 687 millions for the EU during 1999. The bioengineering products reached that year up to $1 \%$ of the total exports of USA with a total amount of US\$ 1.340 millions. Its import of products from OECD countries, especially from Belgium, France, Switzerland and The Netherlands were that same year of US\$ 970 millions. Its most important commercial partners where most of the exports are sent to include: Belgium, Japan, Canada and Germany (Van Beuzekom, 2001).

This indicator allows analyzing the degree of technological delay resulting from the efforts of countries such as Colombia, where it represents approximately US\$ 1.8 millions (constant Colombian pesos as in 2003. Exchange rate $1 \mathrm{US} \$=\$ 2.200 \mathrm{Col}$ ) and $3.7 \%$ of the total governmental investment of the National Biotechnology Program (NBP) made through Colciencias during 1997, and during the following years the tendency remained negative, reaching in 1999 almost US\$ 780.000 and 4.8\% (OCyT, 2004). This situation somehow explains why Colombia reports 8 patents granted to research groups associated with the NBP (OCyT, 2004), whereas the USA already had more than 3.600 patents and Canada more than 500 during the year 2000 (Van Beuzekom, 2001). It could be said that the relation between the investment in biotechnology and the number of patents is more than US\$ 2 million per patent in the USA, US\$ 640.000 in Canada and US\$ 22.000 in Colombia.

On the other hand, the development of biotechnology in LAC has been characterized by being a repetitive model where the research projects do not correspond to the real needs of production and food security, and has a low level of innovation and scientific creativity. Only $2 \%$ out of 30 scientific articles of high impact on biotechnology came from laboratories based within the region (Izquierdo and De La Riva, 2000), despite LAC possessing important 
biodiversity resources to develop innovative products (Roca et al. 2004).

\section{THE STATE OF BIOTECHNOLOGY IN LATIN AMERICA AND THE CARIBBEAN}

Bourinbaiar (2006) recently reviewed developments achieved outside EU that were presented at the BIO 2005 meeting and highlighted progresses done in Argentina and Chile among LAC countries. A comprehensive review was undertaken based on five important books published between 2003 and 2005 by multilateral organizations, showing comparisons and experiences among several LAC countries in terms of scientific and technological capacity, political situation, biosafety, commerce, biodiversity and international markets.

The first study, made by CamBioTec in 14 Latin American countries, Argentina, Bolivia, Brazil, Chile, Colombia, Costa Rica, Cuba, Ecuador, Guatemala, Mexico, Peru, Paraguay, Uruguay and Venezuela, clearly shows that for 2002 the biotechnological industry was represented by 432 companies (including less than 20 companies in the agricultural sector in countries of the Andean Community of Nations (CAN)), where the most outstanding are the BioMinas cluster in Brazil, the agro biotechnological pole of the National Institute of Agricultural Technology (INTA) from Argentina and the Western Biotechnological Pole (Polo Biotecnológico del Oeste) in Cuba. The companies mostly involved with the agricultural sector are in the fields of cell biology and microbiology, with emphasis on the propagation of plant materials to lower cost and time production. Regarding national regulations for the protection of intellectual property rights, microorganisms can be patented in Brazil and Mexico, while in Chile it is possible to patent biotechnological processes (CamBioTec, 2003).

From the second study, financed by Iberoamerican Program for the Development of Science and Technology (CYTED) during 2003, it can be concluded that while the majority of researchers work in the agricultural sector, innovations are not so representative when compared to the pharmaceutical sector. It also shows that one of the topics where the policies of the countries (with the exception of Brazil) have had less result is in the creation of new enterprises with a biotechnological base. This is due to the shortage of monetary resources and the lack of continuity in the national programs and plans (REVYDET, 2003).

The third one, published in 2003 by OAS, CamBioTec, the USA Embassy in Chile and the Chilean Government, shows the results on different topics related to the application of the Cartagena Protocol and foods derived from genetically modified plants. The study shows experiences that allow us to have an overview of the situation, the perspectives and challenges that modern biotechnology brings to agriculture and it pretends to facilitate the discussion on the risks and benefits of biotechnology for the region (OAS et al. 2003).

The fourth study was financed by OAS and published by the Colombian Observatory of Science and Technology (OCyT), presents statistics from Colombia, Costa Rica, Mexico and Venezuela together with the comments from different experts on the construction of indicators in biotechnology. In the different comparisons made with individuals dedicated to $\mathrm{R} \& \mathrm{D}$, research facilities, training programs, projects and products, there is an evident lack of univocal usage of the notion of biotechnology, while in some countries activities of second generation are accounted, and in other countries only the projects involving the use molecular biology and genetic engineering are accounted (OAS and OCyT, 2004).

Finally, during 2005 the Andean Development Corporation (CAF) produced an analysis of the markets and capacities of the five countries of the CAN, to make use of biodiversity. From the CAF's study it can be highlighted that from the 567 research groups from the five participant countries, half of them work for the agricultural sector. According to the indicators developed by Dr. William Roca for the CAF, the Andean region has reached a 52\% of development of the scientific and technological capacity considered optimal to make use of biotechnology and biodiversity. Regarding the financial tendencies, the study reports that from the 22 groups selected from the five countries that get yearly funds for research, they get on average US\$ 97.500, within a range from US\$ 30.000 to US\$ 1.5 millions (CAF, 2005).

In the Network for Technical Cooperation in Agricultural Biotechnology in Latin America and the Caribbean (REDBIO/FAO) there are four case studies at the national level for Argentina, Bolivia, Ecuador and Peru available at www.redbio.org/estud_casos.htm. According to these studies, we can see in the case of Argentina that modern biotechnology has had an enormous influence from multinational companies controlling the market of transgenic seeds, and that there has been important progress on surface area cultivated with GMOs (Diamante and Izquierdo, 2004). Bolivia shows very little progress in biotechnology, especially on laboratories involved in research, enterprises involved in agricultural produce marketing and as licenses for access to genetic resources (Avila and Izquierdo, 2006). Ecuador, on the other side, has had some progress in the research on Andean roots and tubers and on tree tomato but nevertheless, its progress have been very limited, especially with the introduction of GMOs and the use of biodiversity and genetic resources (Wendt and Izquierdo, 2003). Finally Peru has only one request for introducing a GMO from the International Potato Center (CIP), and its progress at the institutional and political levels has not allowed yet the strengthening of the capacities needed for the effective use of the potential represented in biotechnology (Pastor, 2004). 
About the current capacity of the LAC, the data bank CATBIO from the Network for Technical Cooperation in Agricultural Biotechnology in Latin America and the Caribbean (REDBIO/FAO), founded in 1991, provides information on 738 laboratories located in governmental, private and academic institutions from 32 countries in the region, and from 4300 professionals working in areas related to research, regulation, extension, education and diffusion of biotechnology, all of them integrated in the module profREDBIO.

\section{BIOSAFETY: PROGRESS IN LEGISLATION}

Social, economic and ecological implications when adopting biotechnologies and regulatory frameworks on biosafety have been subject to analysis especially when dealing with agricultural applications of LAC countries (Ramírez, 2003). However, the weak inherent regulatory policies have promoted more scientific progress rather than industrial applications in the LAC region (Solleiro and Gálvez, 2002).

Assessments of potential risks that GMOs could generate for human health, food and the environment are undertaken as part of biosafety studies. The risk assessment should be made on the properties of the product, independently of the techniques used for its development. The risks should be evaluated in relation to the characteristics of the transferred gene and the properties of the plant or receptive organism, and the specific ecosystem where the transgenic will be introduced. Another accepted principle, especially in European countries, is the so called Cautionary Principle, on which the inexistence of evidence on the potential harms is not a reason not to make the standards considered necessary to prevent their occurrence (Torres, 1999). Studies have been carried recently on pollen flow from $\mathrm{Bt}$ maize (Peterson et al. 2006) and flow of genes conferring resistance to insects, diseases and herbicides mainly with potato, tomato, eggplant, cabbage, pepper and cucumber have been subject to risk assessment (Ram and Dasgupta, 2004) especially in Europe, where concern on GMOs is evident (Van Den Eede et al. 2004).

The Cartagena Protocol on Biosafety is the regulatory framework subscribed by more than 100 countries in the world and states the agreements for implementing common procedures on biosafety as well as the rules and regulations for safe trans-boundary movement of GMOs discussed mostly in the Article 18, Paragraph 2, with the aim of conserving biodiversity and environment (Pythoud, 2004; Verastegui et al. 2004).

In addition, the activities related to the development and implementation of the national standards, in the frame of the Global Environmental Facility and World Bank (GEFWB) Project: "Capacity development for implementing the Cartagena Protocol on Biosafety -Convention on Biological Diversity in Colombia" aimed to the inter institutional agreement and articulation of the normative and adaptation of each of the points considered in the Cartagena Protocol. The GEF-WB project has been a scenario of interaction among the participant institutions in search of the articulation and implementation of the national normative under effect, related with the implementation of the Cartagena Protocol that has impacted decisively on the articulation of institutional capacities in terms of normative frameworks that allow a better functioning of the dynamics of innovation and new markets (Verastegui et al. 2004).

During 2000, Colombia signed the Cartagena Protocol on Biosafety to the Convention on Biological Diversity, a legally binding instrument that enters into force in our country by means of the Act 740 of 2002, implying the creation of a biosafety system for the country (OAS and OcyT, 2004). Within the context of the Cartagena Protocol, specifically in the items related to the implementation of rules and regulations on biosafety in Colombia, the country already has an acting legislation in the items of uses and applications of GMOs and its derivatives for agricultural, animal and human consumption. Also are defined the competent authorities, the Ministry for Agriculture and Rural Development (MADR), Ministry of Environment, Housing and Territorial Development (MAVDT), the Ministry for Social Protection (MPS), and indirectly the Ministry of Commerce, Industry and Tourism (MCIT) and the Ministry of Foreign Affairs (National Chancellery) as the national focal point for the Cartagena Protocol.

In the Ordeal 4525 of 2005, three National Technical Committees on Biosafety were created as organizations with the power to examine and evaluate the submitted applications, advising on the issuing of administrative acts that authorize the development of activities with GMOs. This ordeal applies to the transboundary movement, transit, manipulation and use of transgenic organisms, and basically divides the competency of national authorities, leaving the responsibility to Colciencias, in accordance with the use of GMOs, which accompanies the MADR and the Colombian Institute for Agriculture (ICA) in aspects related to agriculture, livestock, fisheries, forestry and agro industrial processes, the MAVDT in relation to the environment; and the MPS and National Institute for the Surveillance of Drugs and Food (INVIMA) in relation to human health and feeds.

For food evaluation, the Specialized Court for Food of the INVIMA was created, entity affiliated to the MPS, which by the Ordeal 936 of may 1996 which makes the evaluations that are scientifically pertinent for the approval process for the use in the country of additives, of new products developed by biotechnology and the other products of the competence of the court. Additionally, the ordeal 3075 of 1997 in its article 54 establishes that will be special procedures for food obtained through third generation biotechnologies and/or processes of genetic engineering, with the purpose of awarding the sanitary registry, previous study and favorable concept from the 
Revising Commission - Specialized Court for Food, according to the Ordeal 936 of 1996.

The MPS by Resolution 00485 of March 2005 establishes the technical regulations on the requirements for labeling or tagging that must be accomplished by canned food and raw materials of food for human consumption. This resolution is currently under discussion and will enter in force by the end of 2005. Article 5 of the resolution specifies the information that food labels and tags must bear. Numeral 5.2.2 states that it must be declared on "any food or food ingredient obtained by means of biotechnology, the presence of any allergenic transferred from any of the products listed in the literal paragraph of the present article. When it is not possible to provide adequate information on the presence of any allergenic through the label, the food that contains the allergenic could not be commercialized". According to article 10, "irradiated food or food placed under ionizing radiation and the ones obtained through certain techniques of genetic modification or genetic engineering, must accomplish with the specific regulations for labeling that for its effect the National Government issues". Currently, the government is developing this disposition for the labeling of GMOs for human consumption.

The competent authorities designated have studied the applications submitted for approving the use and commercialization of GMOs and their products, which involve studies on risk assessment, management and monitoring. Since 1998 the CTN of Agricultural Biosafety ICA has received and processed 12 applications, out of which 9 have been approved, each one with its specifications as a commercial crop, field trials under contention and confined research. Regarding the studies on risk assessment and the introduction into Colombia of GMOs, between 2000 and 2001 the CTN started the evaluation of the Bollgard ${ }^{\circledR}$ technology for the case of cotton owned by Monsanto; it is the first case in the country. In this evaluation two studies were made. From the study of pollen flow it was concluded that gene transfer by means of wind dissemination is statistically null (ICA, 2002). A second study concluded that the Bollgard $\AA$ technology had very significant effects on the pest targets, without affecting the beneficial insects such as useful arachnids needed in the pollination of the cotton flower (ICA, 2003).

\section{PUBLIC PERCEPTION}

As new types of transgenic organisms, vaccines and pharmaceutical products are developed and continually introduced into markets, biosafety becomes the main focus of public concern (Wang, 2006). There have been controversies on GMOs release and consumption where mass media have played the major role. Consumer acceptance of GMOs is complex and diverse across cultures (Blaine et al. 2002; McInerney et al. 2004; Bauer, 2005). Countries such as USA, with an export tradition of soybean, canola and maize, developed GM crops to enhance their competitiveness. Regulation issued by the US Food and Drug Administration (FDA) related to production and labelling is objective and expeditious, while the EU has created a complex regulation for GMOs (Vidal, 2003; Fernández-Díez and Corripio Gil-Delgado, 2004; Herrick, 2005).

Between 1998 and 1999, EU invested an annual average near to US\$ 100 million on agrobiotechnologies (Kalaitzandonakes, 2000), at the same time as the application of rules and regulations on labelling for GMOs trade was initiated, which was rejected by large food trading companies as Carrefour and Marks \& Spencer and European citizens in overall (Vidal, 2003; Durant and Legge, 2005). This situation resulted in a significant reduction on soybean and maize imports from USA and in a divided public opinion in Europe, rendering GMOs object of a controversy among consumers.

McCluskey and Swinnen (2004) state that 90\% of consumers receive information on food and biotechnology via press and television, but there is not any comprehensive information body to ensure the creation of a risk public perception. For instance, $45 \%$ in Canada (Einsiedel, 2000) and $30.1 \%$ in the USA (Hornig, 2000) think that biotechnology is risky. In the EU $63 \%$ of the citizens think that decisions must be based on moral and ethical considerations. On the other side, those who believe that we have the right to exploit nature for human wellbeing (70\%), are prone to think that biotechnology and genetic engineering could have a positive effect on life quality for the next twenty years (Durant and Legge, 2005; Eurobarometer, 2005).

Colombia is aware of the debate between the movements that are trying to return to the ancestral agriculture by promoting through green labels and certificates the identification of organic products, and the movements that promote the consumption of transgenic food that provide benefits for the producers, consumers and the environment.

The public perception on biotechnology was analyzed in Colombia through two different sources of information. The first one, understood as the formal speech, transmitted through the media and documents released by the governmental institutions, which make opinion, inform, take decisions and rule the activities that make use of biotechnology. The second one, based on oral information, includes the research groups, education institutions, national and multinational companies, consumer associations and environmental movements, that use speeches that fundament the realities in the public sphere. These types of studies have also been conducted in Europe by means of surveys in order to open the public debate on GMOs in the way as Pidgeon et al. (2005) did in Great Britain.

During 2004 Agro-Bio gathered press information to study the situation on the positions towards the GMOs. Of the 47 
opinion articles analyzed, 54\% reveal a positive position, while the remaining $46 \%$ is divided in equal parts between negative and neutral. From the most representative titles, we highlighted in the newspaper El Colombiano: "Cotton: giant recovering", (Feb. 23), "Genetically modified organisms-GMOs", (April 26); in the newspaper: Portafolio: "Biotechnology and development", (Feb. 25) and "The debate on transgenics", (Oct. 17); from El Universal we highlight: "The century of biotechnology", (Jun. 8); in La República, "Insects and Bt" (Sep.6); and finally from the newspaper $\mathrm{El}$ Tiempo we highlight: "Biodiversity is not patentable" (Jun. 22) and "What's on with biotechnology in Colombia?, by that time head of the National Program on Biotechnology of Colciencias, and an article written by Alfonso López Michelsen, former President of Colombia and a key person in the political sphere at the national level, and published in the opinion column from the November 21, 2004 edition, entitled "Positive results in Colombia: Agrobiotechnology in 2004", where he gives his point of view on the benefits that the country has received thanks to policies promoting the adoption of GM crops, especially the progress in cotton.

Regarding the second source of information, one of the cases is the result of a research done by the Universidad del Rosario that allows to conclude that the overall knowledge of the citizens is little, and that from the semantic point of view, interviewees associate biotechnology with food that has been altered, manipulated and transformed, and that have a connection to laboratories working on genetics, where abnormal, artificial, good, improved, natural and preserved produce are obtained (Perales, 2001). Another study conducted by ICA during 2002 for the city of Bogotá, shows that the attitude towards the consumption of GM food is $42 \%$ positive and $12 \%$ indifferent.

The perception on the "chemicals" and the "transgenic crops" is currently generalized in terms of the alteration of the natural composition of food, and the associated impression of risks to health that are brought along their consumption (Perales, 2001). The election of a certain organic produce, a transgenic produce, or one produced by conventional methods is tightly related to different social groups. While in the upper strata groups the decision making is based on a wide spectrum of criteria, in the lower strata the decisions are related to their limited economical capacity, where the price is the main criterion. The former could get access to organic produce, which have in the country a restricted offer due to only $1 \%$ of farmed lands with them and only $10 \%$ of their production destined to the national markets, while the latter must get the more accessible produce according to their income.

Globalization, the debate on food security and potential risks of biotechnology, as well as strong pressures from interest groups such as multinational companies and environmentalists, all demand starting education programmes similar to the United Nations University Biotechnology Programme for LAC, to promote an open dialogue among scientists, opinion leaders and mass media, that would act as the basis to support the technological shift during economic development (Braun, 2002).

In order to generate an objective public perception on transgenics, it is necessary to have suitable information sources showing scientific evidence. For this, there have been activities such as workshops, meetings, seminars and congresses at the national and international level, aimed to different sectors of the society. Some of the main groups that these activities are aimed to are government officers, policy makers, media, professional associations, scholars and the productive sector. During these meetings, several topics such as the use and development of biotechnologies, biosafety, risk management and assessment of GMOs, and regulatory frameworks are discussed (Juanillo, 2001; Verastegui et al. 2004).

\section{INTELLECTUAL PROPERTY RIGHTS}

Intellectual property is a legal system that provides exclusivity rights to persons and companies for the commercial exploitation of their creations and inventions. The granting of Intellectual Property Rights (IPRs) has been justified to assure the return of the inversion that is made to develop an invention. This is especially critical when dealing with new technologies, where biotechnology has a protagonist role.

Brazil and other LAC countries have an immature national innovation system where scholar and scientific progress receive more support than industrial developments do, particularly due to the construction process of a normative framework on intellectual property (Coutinho et al. 2003). The protection of intellectual property rights in agricultural and pharmacy biotechnology is also the cornerstone of the dispute about bio-piracy. The international protection of intellectual property has been a contentious issue between developed and developing countries (Kerr et al. 1999; Forero-Pineda, 2006).

The first patents in modern biotechnologies appeared during the 80 's, when the patent to recombinant DNA technology was granted in the USA to Stanley Cohen and Herbert Boyer, which has given more than 200 licenses to pharmaceutical and biotechnological companies and received more than US\$ 100 million in royalties (www.genome.gov/Pages/Education $/ \mathrm{Kit} / \mathrm{main} . \mathrm{cfm}$ ?pageid= 6). Pray and Naseem (2005) show how patents on genetic transformation techniques stimulate private investment and reveal how benefits derived from patenting exceed the costs. However, there have been conflicts regarding the protection of intellectual property rights on genetic transformation technologies, especially in the case of viral vectors, Agrobacterium, and other bacteria, among governmental institutions, universities and the private sector (Chung et al. 2006). 
It is important to mention that at the World Intellectual Property Organization (WIPO), a conflict arose in 2000 between the objectives of the Convention on Biological Diversity (CBD) and the Legal Aspects of Intellectual Property Relating to Trade (ADPIC), WTO-(Aspects des droits de propriété intellectuelle qui touchent au commerce) around the discussion on the Patent Law Treaty (PLT), that led to the creation of an Intergovernmental Committee on Genetic Resources, Traditional Knowledge and Intellectual Property. Also in the Committee on Trade and Environment (CTE) and the ADPIC Council of the WTO there have been discussions, especially referring to the article $27.3 \mathrm{~b}$ ) that discusses two aspects of patentability. The first one excludes patents on plants and animals, including those genetically modified, as well as animal breeds and plant varieties. The second one includes the obligations of the countries to guarantee the protection of microorganisms, non-biological processes, microbiological processes, and plant varieties through either patents or an effective sui generis system, or a combination of both (Vivas, 2001).

The majority of innovations on plant biotechnology are subject to be patented, even that the coverage range varies considerably according to the country and the technology. The patents are used to protect biotechnological tools, reagents, genetic sequences, and transformation, regeneration and diagnosis processes. The obtainment of a GMO includes the insertion of a construct containing a gene of interest, a selection marker gene, a promoter, and other sequences that could be patented. The insertion can be achieved by means of a transformation method that can be patented if it has novelties when compared to the original method, whether using equipment or any other material for which an exception can be done with a research activity. Obtaining a patent on a new gene does not guarantee the freedom to operate when other technologies or processes could be used for the gene of interest to work in the plant.

The regime of patents affects biotechnology from its use in plant improvement by means of hybridization to the development of transgenic plants. The technologies for the diagnosis and the equipment and procedures used to study the genomes are susceptible of patenting. Nevertheless, when a new variety could not be a novelty or protected genetic material, if this development is related with the use of techniques or processes, it could be subject to licensing or restriction for plant breeder's rights.

In the same way, and according to what is stated in article 20 of the Decision 486 of the CAN, it is considered that inventions whose commercial exploitation on the territory of the respective member country makes an attempt against public order, moral, health or life of people or animals, or the preservation of plants or the environment, are not patentable. Finally, are not subject to patenting, plants or animals and essentially biological procedures for the production of plants and animals that are not non-biological nor microbiological procedures, neither the therapeutic or surgical processes for the treatment of humans or animals, neither the methods of diagnosis applied to human beings or animals.

In Colombia the CAN disposition is ruled by the Decree 2591 from December 13, 2000 and the regulating resolution 210 from January 15, 2001. The IPRs are managed by the Surveillance of Industry and Commerce (SIC), adhered to the MCIT, which in turn is in charge of giving the patents and registration of marks. By means of Law 243 of 1995 plant breeder's rights were established and in 1996 the country adhered to the act of International Union for the Protection of New Varieties of Plants (UPOV) of 1978. The legal framework on IPRs is basically given by the Andean decisions 345 for the UPOV and 486 for industrial property. Within the analysis it should be taken in account what was agreed in the ADPIC agreement and the world context. It should be especially considered the aspects related with genetic material, derived products and the non tangible component associated with them.

Plant breeder's rights have a more limited coverage than patents because they only protect the variety, but not the obtainment procedures nor its uses. For a variety to be subject to protection it must have the following characteristics: novelty, which means it has never been commercialized; distinctiveness, which can be differentiated clearly from other known varieties, uniformity and stability. The time coverage of the protection is 15 years for short-cycle crops and 20 years for permanent crops.

According to SIC, plants and genes are not susceptible of patenting in Colombia, but non-plant GMOs and specific processes made by microorganisms can both be patented. That means the biotechnological processes that imply the use of biological material for the production or transformation of products as is the case of fermentation, are patentable. Equally are patentable the procedures to obtain transgenic plants, a plant cell that has been transformed, nevertheless, the complete transgenic plant is not, neither any of its reproductive structures. Modified genes, recombinant DNA, cDNA, vectors that hold genes and do not exist as such in nature, and cells with foreign genes are all patentable in Colombia.

Finally, the challenges on intellectual property derive from how to harmonize the purposes of science, industry and society: a scientific development that generates Basicknowledge, with an application beneficial for improving life quality for humankind; an industry that makes innovations and has a compensation system for its investment; and a vigilant society receptive to innovations that are at its reach and constitute a source of social and economical well-being. 


\section{ACCESS TO GENETIC RESOURCES}

The United Nations Environment Programme (UNEP) promoted the creation of the CBD, signed by 150 government leaders in 1992. "The Convention recognizes that biological diversity is about more than plants, animals and micro organisms and their ecosystems - it is about people and our need for food security, medicines, fresh air and water, shelter, and a clean and healthy environment in which to live" (CBD, 1992). One of the main commitments contained in the CBD, which was ratified by Colombia by means of the Act 165 of 1994, is the one referred to the creation by each country of conditions enabling access and conservation of genetic resources. The CBD states in its objectives that an adequate access to genetic resources should be allowed and appropriate transference of technology required for investigating these resources should be facilitated.

Colombia recognized the Andean Decision 391 of 1996 to establish a common regime of access to genetic resources, understanding for genetic resources "any material of biological nature containing genetic information of actual or potential utility or value" and for access "obtainment and utilization of genetic resources conserved in situ or ex situ, their derived products, or -whether the case- their intangible components, with the purpose of research, biological prospecting, conservation, industrial application or commercial use."

Colombian flora is legally protected by means of the Act 299 of 1996 and botanic gardens are regulated as scientifically organized collections of living plants. Botanic gardens are enabled to manage herbaria and plant germplasm in the form of genebanks (or seedbanks), shall conduct permanent programmes on basic research, education, and ex situ and in situ conservation. One of their major goals is genetic diversity conservation. In addition, Article 16 defines the activities to be carried out by the Colombian National Herbarium-Natural History Museum of the Instituto de Ciencias Naturales, Universidad Nacional de Colombia, the herbarium of the Instituto de Investigación de Recursos Biológicos Alexander von Humboldt along with all the other official herbaria, as well as those affiliated to the Colombian Association of Herbaria.

Besides, Decree 1603 of 1994 orders the Instituto de Investigación de Recursos Biológicos Alexander von Humboldt to keep gathered the biological collections resulting from scientific plant collecting permits and those obtained by regional environmental agencies and other research institutes ascribed to the MAVDT. The Instituto de Investigación de Recursos Biológicos Alexander von Humboldt within a work leaded by Ricardo Torres in 2004, identified 25 germplasm banks, 13 botanic gardens and 36 herbaria, totalling 22,750 germplasm accessions, 14,490 accessions container in botanic gardens, and 1,344,000 exsiccates.
Worthy to note is the fact that the country exhibits the highest biodiversity index (0.935) when compared to Mexico (0.928) and Brazil (0.877), rendering Colombia a megadiverse country par excellence (Roca et al. 2004). Despite, the country had some difficulties to make good use of this advantage. Calle (1996) described some of the technical, legal and sociocultural difficulties that Colombia have to face on the access to genetic resources, and ZerdaSarmiento and Forero-Pineda (2002) described some aspects in the relationship between large firms and traditional knowledge in ethnic groups in some LAC countries that will be taken into account.

\section{CONCLUDING REMARKS}

It is well known that one of the potentials that Colombia has in the agricultural ambit is on its large biodiversity and variety of climatic levels and altitudinal ranges, but its sustainable use will occur only after the potential species and its market niches have been positively identified, to permit the country to be competitive at the national and international markets, solving problems especially for food and pharmacopoeia. The production and marketing of agricultural products and natural resources demands today, more than ever, certifications, guarantees of plant health, resistance to biotic and abiotic factors, innocuousness and highly productive performance, and also the development of productive chains allowing to hold demands in time. This is how the exposed cases in Colombia allow seeing the way on how networks were created and consolidated among heterogeneous actors, where science and technology achieved their contribution for the inclusion of small producers in the dynamics of global competition with the use of biotechnology (Orozco and Chavarro, 2006). Nevertheless, there is still much to be done, especially in the sustainable articulation of productive chains and the creation of competitive sustainable advantages making use of biotechnology as a mechanism for innovation.

The present study identifies three key aspects for agricultural biotechnology development in Colombia: 1) a substantial investment increase, which should be focused on the obtainment of patentable industrial applications utilizing biodiversity and genetic resources; 2) an effort increase of governmental and non governmental institutions in implementing and applying regulations on biosafety, intellectual property rights and access to genetic resources, by stimulating investment and innovation; and 3) providing opportunities for open discussion and wide dissemination of information that will favour building an objective public perception and thus progressing towards a decision-making capacity of consumers and the general public.

It is also clear that the only way to overcome many of the limiting factors that have been faced by the potential use and development offered by biotechnology in a country like Colombia, is through a state policy that overcomes the 
changes generated in each government, and this is why the policy proposal Visión Colombia II Centenario 2019, which contains a chapter entitled "Making use of biotechnology, biodiversity and genetic resources" is the opportunity to achieve biotechnology to be projected in the long term and be inserted into the productive systems and environmental sustainability, generating impacts especially for small producers, understood as the increment of their possibilities to get access to a better life quality, the enjoyment of wellbeing and to expand their possibilities of freedom in the process of human development. The key point of this policy is to generate added value to biodiversity and promote the industrial development of products, emphasizing on patent obtainment by research groups and companies.

Colombia requires a multisectorial institution a) facilitating the incorporation of benefits derived from biotechnology in productive systems by enabling biotechnology transference and linkage, b) conducting a permanent monitoring of activities, their impact and inclusion into various sectors of application, and c) providing advisory on intellectual property, technological transference, biosafety, public perception, access to genetic resources and markets. It is likewise required from such an institution the coordination of policy design and implementation based upon prospective surveys, exercises on technological surveillance, market surveys and sociocultural analyses.

The information compiled through interviews, information systems and bibliography sources allowed us to make an evaluation of the generation, application, implementation and use of agricultural biotechnology by different social actors that through policies, programs, cooperation networks and transference activities, have made possible to incorporate biotechnology into some agricultural productive systems in the country (Schuler and Orozco, 2005).

The study cases developed by many LAC countries, as an initiative of REDBIO/FAO, will allow to know the enormous potential that these countries count with, to bring together the generating actors of science and technology, so that through an associated work, supervised by technological assistance, LAC may represent an integrated model of technological development, not only for agricultural biotechnology, but also for the other areas into which there is applicability such as health, environment and industry. This study is inscribed into the general frame of contributions that have been produced with the aim to analyze the strategy that integrates science, technology and society, as the engine for the development of nations.

\section{ACKNOWLEDGMENTS}

We would like to thank the efforts made by Colciencias, the OCyT and the CTS group of the Universidad Nacional de Colombia, for enabling the country to lead the implementation of a ScienTI platform for LAC that compiles the information of the curricula vitae of researchers and research groups. Thanks to this tool, it is possible to have good quality information on scientific and technological activities in Colombia, especially to promote scientific collaboration and the decision-makings aimed to the reorientation of research activities. We would also want to thank all the institutions and people we interviewed during this research who are listed in the full document of this case study available at http://www.redbio.org/e_casos/colombia.pdf. Finally, we thank Sandra Constantino for revising the manuscript and Diego Andrés Chavarro for his contributions in the ScienTI system.

\section{REFERENCES}

AVILA, Teresa and IZQUIERDO, Juan. Management of the appropriate agricultural biotechnology for small producers: Bolivia case study. Electronic Journal of Biotechnology [online]. 15 January 2006, vol. 9, no. 1 [cited June 2006]. Available from Internet: http://www.ejbiotechnology.info/content/vol9/issue1/full/4/ index.html. ISSN 0717-3458.

BAUER, Martin W. Public perceptions and mass media in the biotechnology controversy. International Journal of Public Opinion Research, 2005, vol. 17, no. 1, p. 5-22.

BLAINE, K.; KAMALDEEN, S. and POWELL, D. Public perceptions of biotechnology. Journal of Food Science, November 2002, vol. 67, no. 9, p. 3200-3208.

BOURINBAIAR, Aldar S. Recent developments in biotech industry outside of the USA and Western Europe: Report from BIO 2005. Electronic Journal of Biotechnology [online]. 15 April 2006, vol. 9, no. 2 [cited June 2006]. Available from Internet: http://www.ejbiotechnology.info/content/vol9/issue2/full/5/. ISSN 0717-3458.

BRAUN, Richard. People's concerns about biotechnology: Some problems and some solutions. Journal of Biotechnology, September 2002, vol. 98, no. 1, p. 3-8.

BYERLEE, Derek and FISCHER, Ken. Accessing modern science: Policy and institutional options for agricultural biotechnology in developing countries. World Development, June 2002, vol. 30, no. 6, p. 931-948.

Corporación Andina de Fomento (CAF). Biotecnología para el desarrollo sostenible de la biodiversidad. Capacidades locales y mercados potenciales [online]. Caracas, 2005, 114 p. ISBN: 980-6810-03-1 [cited February 2006]. Available from Internet: http://www.caf.com/attach/11/default/biodiversidad-full.pdf.

CALLE, Rosángela. Juridical and sociocultural problems on the definition of a law concerning property, usage and 
access to genetic resources in Colombia. Journal of Ethnopharmacology, April 1996, vol. 51, no. 1-3, p. 127146.

CamBioTec. La biotecnología en América Latina: Panorama al año 2002. CamBioTec-IDRC, Ottawa, 2003. 237 p. ISBN 987-20494-3-2.

Convention on Biological Diversity (CBD). United Nations Environment Programme, CDD-UNEP [online]. 1992 [cited February 2006]. Available from Internet: http://www.biodiv.org/doc/legal/cbd-es.pdf.

$\mathrm{CHAN}$, Phoebe H. International patent behavior of nine major agricultural biotechnology firms. AgBioForum, 2006, vol. 9, no. 1, p. 59-68.

CHUNG, Sang-Min; VAIDYA, Manjusha and TZFIRA, Tzvi. Agrobacterium is not alone: Gene transfer to plants by viruses and other bacteria. Trends in Plant Science, January 2006, vol. 11, no. 1, p. 1-4.

COUTINHO, Marilia; BALBACHEVSKY, Elizabeth; OLIVEIRA-HOLZHACKER, Denilde; PATRAO, Diogo Da Costa; ZORZETTO-VENCIO, Ricardo Nicoliello; MEDEIROS DA SILVA, Rodrigo Luiz; GOMES LUCATELLI, Márcio Luís; DOS REIS, Lucimara Flavio and MARIN, Maria Angélica. Intellectual property and public research in biotechnology: The scientists opinion. Scientometrics, November 2003, vol. 58, no. 3, p. 641-656.

DIAMANTE, Alicia and IZQUIERDO, Juan. Manejo y gestión de la biotecnología agrícola apropiada para pequeños productores: estudio de caso-Argentina [online]. REDBIO/FAO, 2004 [cited December 2005]. Available from Internet: http://www.redbio.org/estud_casos.htm.

DURANT, Robert F. and LEGGE, Jerome S. Public opinion, risk perceptions, and genetically modified food regulatory policy: Reassessing the calculus of dissent among European citizens. European Union Politics, 2005, vol. 6 , no. 2 , p. 181-200.

EINSIEDEL, Edna F. Cloning and its discontents: A Canadian perspective. Nature Biotechnology, September 2000, vol. 18 , no. 9 , p. 943-944.

ERNST and YOUNG. Integration [online]. Ernst and Young's Eighth Annual Life Sciences Report, 2001. 83 p. [cited August 2005]. Available from Internet: http://www.ey.com/GLOBAL/content.nsf/UK/HS_-_Library__Integration.

EUROBAROMETER. Social values, science and technology [online]. Special Eurobarometer 225/wave 63.1TNS Opinion and Social, European Commission, 2005. 336 p. [cited October 2005]. Available from Internet: http://ec.europa.eu/public_opinion/archives/ebs/ebs_224_re port_en.pdf.
FERNÁNDEZ-DÍEZ, María Cármen and CORRIPIO GILDELGADO, María Reyes. Regulatory factors affecting the agri-food biotechnology sector in the European Union. International Journal of Biotechnology, July 2004, vol. 6, no. 2-3, p. 260-280.

FORERO-PINEDA, Clemente. The impact of stronger intellectual property rights on science and technology in developing countries. Research Policy, July 2006, vol. 35, no. 6, p. $808-824$.

HEISEY, Paul W.; KING, John L. and RUBENSTEIN, Kelly D. Patterns of public-sector and private-sector patenting in agricultural biotechnology. AgBioForum, 2005, vol. 8 , no. $2-3$, p. 73-82.

HERRICK, Clare B. 'Cultures of GM': Discourses of risk and labelling of GMOs in the UK and EU. Area, September 2005, vol. 37, no. 3, p. 286-294.

HORNIG, Sussana. US public opinion divided over biotechnology? Nature Biotechnology, 2000, vol. 18, no. 9, p. $939-942$.

HUETE-PÉREZ, Jorge A.; OROZCO, David A.; SINGER, Peter A. and DAAR, Abadía S. Biotech gap between north and south. Science, December 2001, vol. 294, no. 5550, p. 2289-2290.

Instituto Colombiano de Agricultura (ICA). Estimación de la distancia a la cual el polen del algodonero (Gossipium hirsutum L) es transportado por polinizadores. Bogotá, ICA, 2002. 23 p.

Instituto Colombiano de Agricultura (ICA). Evaluación del efecto de la tecnología Bollgard ${ }^{\circledR}$ sobre poblaciones de artrópodos y anélidos en el algodonero (Gossipium hirsutum L). Bogotá, ICA, 2003. 32 p.

IZQUIERDO, Juan and DE LA RIVA, Gustavo A. Plant biotechnology and food security in Latin America and the Caribbean. Electronic Journal of Biotechnology [online]. 15 April 2000, vol. 3, no. 1 [cited February 2006]. Available from Internet: http://www.ejbiotechnology.info/content/vol3/issue1/full/1/ index.html. ISSN 0717-3458.

JUANILLO Jr, Napoleon $\mathrm{K}$. The risks and benefits of agricultural biotechnology: Can scientific and public talk meet? American Behavioral Scientist, 2001, vol. 44, no. 8, p. $1246-1266$.

KALAITZANDONAKES, Nicholas. Agrobiotechnology and Competitiveness. American Journal of Agricultural Economics, December 2000. vol. 82, no. 5, p. 1224-1233. 
KERR, William A; HOBBS, Jill E. and YAMPOIN, Revadee. Intellectual property protection, biotechnology and developing countries: Will the TRIPs be effective? AgBioForum, 1999, vol. 2, no. 3-4, p. 203-211.

McCLUSKEY, Jill J. and SWINNEN, Johan F.M. Political economy of the media and consumer perceptions of biotechnology. American Journal of Agricultural Economics, December 2004, vol. 86, no. 5, p. 1230-1237.

McINERNEY, Claire; BIRD, Nora and NUCCI, Mary. The flow of scientific knowledge from lab to the lay public: The case of genetically modified food. Science Communication, 2004, vol. 26, no. 1, p. 44-74.

National Science Foundation (NSF). Total R\&D and lower bound biotechnology by industry and company size: 2001 . In: NATIONAL SCIENCE FOUNDATION. Science \& Engineering Indicators 2004 [online]. 2004 [cited August 2005]. Available from Internet: http://www.nsf.gov/statistics/seind04/tables.htm\#c0.

Observatorio Colombiano de Ciencia y Tecnología (OCyT). Indicadores de ciencia y tecnología Colombia. Observatorio Colombiano de Ciencia y Tecnología, 2004. 170 p. ISBN 958-33-6723-0.

Organization of American States and Observatorio Colombiano de Ciencia y Tecnología (OAS - OcyT). Construcción de indicadores en biotecnología. Región comprendida por cuatro países de América Latina y el Caribe [online]. Organization of American States and Observatorio Colombiano de Ciencia y Tecnología, 2004. 192 p. ISBN 958-33-6965-9 [cited November 2005]. Available from Internet: http://www.science.oas.org/english/doc/Indicadores_en_Bi otecnología_OEA_2004.pdf.

OAS; CamBioTec; EEUA; SAG and CONICYT Chile. Bioseguridad y comercio internacional de alimentos transgénicos en las Américas: Decisiones y desafíos. Organization of American States, 2003. 255 p. ISBN: 95629-992-7.

OROZCO, Luis Antonio and CHAVARRO, Diego Andrés. De historia y sociología de la ciencia a indicadores y redes sociales. Análisis de la biotecnología para el estudio de comunidades científicas en el marco de los Programas Nacionales de Ciencia y Tecnología [online]. Observatorio Colombiano de Ciencia y Tecnología, 2006. 195 p. ISBN: 958-33-8813-0 [cited April 2006]. Available from Internet: http://www.ocyt.org.co/libro_de_hist_a_ind.php.

PASTOR, Santiago. Manejo de la Biotecnología Apropiada para Pequeños Productores: Estudio de Caso-Perú [online]. REDBIO/FAO, 2004, 53 p. [cited February 2005]. Available from Internet: http://www.redbio.org/estud_casos.htm.
PERALES, Carlos. Percepciones públicas de la biotecnología, el caso de los alimentos transgénicos. Universidad Colegio Mayor de Nuestra Señora del Rosario, Escuela de Ciencias Humanas. Informe de investigación No. 1222-10-10775, Colciencias, 2001. 214 p.

PETERSON, Robert K.D.; MEYER, Steven J.; WOLF, Amy T.; WOLT, Jeffrey D. and DAVIS, Paula M. Genetically engineered plants, endangered species, and risk: A temporal and spatial exposure assessment for karner blue butterfly larvae and Bt maize pollen. Risk Analysis, June 2006, vol. 26, no. 3, p. 845-858.

PIDGEON, Nick F.; POORTINGA, Wouter; ROWE, Gene; JONES, Tom H. and WALLS, John. Using surveys in public participation processes for risk decision making: The case of the 2003 British GM nation? Public debate. Risk Analysis, April 2005, vol. 25, no. 2, p. 467-479.

PRAY, Calr E. and NASEEM, Anwar. Intellectual property rights on research tools: Incentives or barriers to innovation? Case studies of rice genomics and plant transformation Technologies. AgBioForum, 2005, vol. 8, no. 2-3, p. 108-117.

PYTHOUD, François. The Cartagena protocol and GMOs. Nature Biotechnology, December 2004, vol. 22, no. 11, p. 1347-1348.

RAM, R.B. and DASGUPTA, S.K. Transgenic vegetable crops. Journal of New Seeds, 2004, vol. 6, no. 4, p. 411431.

RAMÍREZ, José Luis. Biosafety why and for whom? Latin America on target. Interciencia, November 2003, vol. 28, no. 11. p. 669-672.

REVYDET. Biotecnología: Políticas públicas y aceptación social en Argentina, Brasil, Chile, Colombia, Cuba, Ecuador, España y México. CYTED - Subprograma III: Biotecnología. Red Multimodal de Vinculación y Desarrollo Biotecnológico, Buenos Aires, 2003. 127 p. ISBN: 987-20494-4-0.

ROCA, W.; ESPINOZA, C. and PANTA, A. Agricultural applications of biotechnology and the potential for biodiversity valorization in Latin America and the Caribbean. AgBioForum, 2004, vol. 7, no. 1-2. p. 13-22.

SCHULER, Ingrid and OROZCO, Luis Antonio. Manejo y gestión de la biotecnología agrícola apropiada para pequeños productores. Estudio de Caso-Colombia [online]. REDBIO/FAO, 2005, 53 p. [cited January 2006]. Available from Internet: http://www.redbio.org/e_casos/colombia.pdf.

SOLLEIRO, José Luis and GÁLVEZ, Amanda. Latin American biosafety regulatory framework. International Journal of Biotechnology, 2002, vol. 4, no. 4, p. 306-320. 
SPIELMAN, David J.; COHEN, Joel I. and ZAMBRANO, Patricia. Will agbiotech applications reach marginalized farmers? Evidence from developing countries. AgBioForum, 2006, vol. 9, no. 1, p. 23-30.

TESTA, Pablo. Indicadores de biotecnología y tecnología de alimentos una revisión de la experiencia internacional reciente. In: Reunión-Taller sobre Construcción de Indicadores en Biotecnología y Tecnología de Alimentos $\left(8^{\text {th }}-11^{\text {th }}\right.$ October, 2002, Universidad Técnica de Ambato, Ambato, Ecuador). Organization of American Status (OAS), 2002.

THUMM, Nikolaus. Patents for genetic inventions: A tool to promote technological advance or a limitation for upstream inventions? Technovation, December 2005, vol. 25 , no. 12 , p. $1410-1417$.

TOLLENS, Eric; DEMONT, Matty and SWENNEN, Rony. Agrobiotechnology in developing countries: North-South partnerships are the key. Outlook on Agriculture, December 2004, vol. 33, no. 4, p. 231-238.

TORRES, Ricardo. La evaluación socioeconómica en el régimen de bioseguridad. In: ARAMENDIS, R. ed. Bioseguridad. Un nuevo escenario entre las consideraciones comerciales, medioambientales $y$ socioeconómicas. Organization of American States-OAS and Conciencias, Tercer Mundo Editores S.A., 1999, p. 2030 .

U.S. Department of Commerce. A survey of the use of biotechnology in U.S. industry [online]. Washington DC, U.S. Department of Commerce Technology Administration Bureau of Industry and Security, 2003. 170 p. [cite October 2005]. Available from Internet: http://www.technology.gov/reports/Biotechnology/CD120a _0310.pdf.

VAN BEUZEKOM, Brigitte. Biotechnology Statistics in OECD Member Countries: Compendium of Existing National Statistics [online]. STI Working Paper 2001/6, Paris, OECD, 2001. 113 p. [cited August 2006]. Available from Internet: http://www.olis.oecd.org/OLIS/2001DOC.NSF/ c125639b00523150c12560da00393ee1/c1256985004c66e3c1256a c600350f21/ \$FILE/JT00112476.PDF.

VAN DEN EEDE, G.; AARTS, H.; BUHK, H.-J.; CORTHIER, G.; FLINT, H.J.; HAMMES, W.; JACOBSEN, B.; MIDTVEDT, T.; VAN DER VOSSEN, J.; VON WRIGHT, A.; WACKERNAGEL, W. and WILCKS, A. The relevance of gene transfer to the safety of food and feed derived from genetically modified (GM) plants. Food and Chemical Toxicology, July 2004, vol. 42, no. 7, p. 1127-1156.

VERASTEGUI, Javier; MARTÍNEZ, Victor; ROCA, Willy; DE PEÑA, Myriam and GIL, Lionel. The multinational biosafety project of the Organization of American States. Electronic Journal of Biotechnology [online]. 15 April 2004, vol. 7, no. 1 [cited August 2005]. Available from Internet: http://www.ejbiotechnology.info/content/vol7/issue1/full/6/ index.html. ISBN 0717-3458.
VIDAL, Daniel. Alimentos transgénicos en la Unión Europea: Percepción pública. In: DELLACHA, Juan M. ed. Biotecnología: Políticas públicas y aceptación social en Argentina, Brasil; Chile, Colombia, Cuba, Ecuador, España y México. Subprograma III: Biotecnología. Red Multimodal de Vinculación y Desarrollo Biotecnológico 2003. Buenos Aires, 2003, p. 91-94. ISBN 987-20494-4-0.

VIVAS, David. Análisis de la relación del ADPIC y la implementación nacional de la CBD: El caso del sistema de acceso y el desvelo del origen de los recursos genéticos en Venezuela [online]. UNCTAD. Estudio preparado para Diplomacia Comercial/UNCTAD, 2001. 48 p. [cited February 2006]. Available from Internet: http://www.comunidadandina.org/desarrollo/2_David\%20V ivas.pdf.

WANG, Jialian. Transgenic organisms and biosafety. Chinese Journal of Ecology, March 2006. vol. 25, no. 3, p. 314-317.

WATAL, Jayashree. Intellectual property and biotechnology: trade interests of developing countries. International Journal of Biotechnology, 2000, vol. 2, no. 13, p. 44-55.

WENDT, Jan and IZQUIERDO, Juan. Management of appropriate agricultural biotechnology for small producers: Ecuador case study. Electronic Journal of Biotechnology [online]. 15 April 2003, vol. 6, no. 1 [cited January 2006]. Available from Internet: http://www.ejbiotechnology.info/content/vol6/issue1/issues /02/. ISSN 0717-3458.

ZERDA-SARMIENTO, Alvaro and FORERO-PINEDA, Clemente. Intellectual property rights over ethnic communities' knowledge. International Social Science Journal, March 2002, vol. 54, no. 171, p. 99-114. 